\title{
SISTEM INFORMASI MANAJEMEN PENDIDIKAN
}

\author{
siskanovsatia13@gmail.com
}

\begin{abstract}
Abstrak
Di era globalisasi ini, teknologi sangat mendukung perkembangan perusahaan/organisasi, dengan adanya teknologi, melancarkan aktivitas yang dikelola organisasi. Penerapan Sistem Informasi Manajemen disekolah membantu pihak sekolah untuk mengelola sekolah dengan mudah.
\end{abstract}




\section{PEMBAHASAN}

\section{A. Pengertian Sistem Informasi Manajemen}

Menurut I. Ackof sistem adalah suatu kesatuan yang terdiri dari kesatuan secara konseptual dan saling berkaitan. Sistem Informasi Manajemen adalah pengelolaan dari pihak internal untuk mengendalikan organisasinya. Di dunia pendidikan Sistem Informasi Manajemen merupakan suatu server yang terkoneksi dengan jaringan internet yang meliputi data sekolah dan dikelola oleh pihak internal sekolah.

\section{B. Konsep Dasar Sistem Informasi Manajemen Sekolah}

Fungsi dari informasi yaitu sebagai perantara antara semua bagian organisasi hingga bagian tersebut tidak terisolasi dengan bagian lain. Sistem yang sudah lama perlu diperbaiki atau bahkan diganti, dapat disebabkan oleh beberapa hal, yaitu :

1. Pengolahan data kurang efisien

2. Kurang berkembangnya sekolah

3. SDM tidak mendukung perubahan

4. Kurangnya biaya dalam melakukan perubahan

5. Manajer sekolah kurang memotivasi anggotanya.

C. Dampak Dari Penerapan SIM Pendidikan Terhadap Etika dan Sosial

Adapun menurut Eti Rochaety pengaruh positifnya yaitu lebih efisiennya kinerja karena teknologi informasi dapat posisi penyambung komunikasi dari dua tempat yang berkepentingan, dan juga mengahpus batas waktu untuk operasi internasional. Adapun dampak negatifnya yaitu berkurangnya SDM karena pekerjaannya sudah digantikan oleh teknologi yang canggih.

Penerapan SIM juga dapat menghemat waktu dan tempat, selain memudahkan pihak internal dalam mengola data siswa yang begitu banyak. 


\section{PENUTUP}

A. Kesimpulan

Dari ulasan diatas dapat ditarik kesimpulan bahwa SIM merupakan proses operasional sekolah. SIM sangat berpengaruh terhadap perkembangan organisasi. Penerapan SIM pendidikan disekolah memudahkan pihak sekolah dalam mengolah sekolah. 